\title{
RELATING TO THE SEMANTIC ANALYSIS \\ OF THE CONCEPT HUMAN IN THE STRUCTURE \\ OF THE PHRASEOLOGICAL FIELD
}

\section{ЩОДО СЕМАНТИЧНОГО АНАЛІЗУ \\ ФРАЗЕОЛОГІЧНОГО ПОЛЯ КОНЦЕПТУ ЛЮДИНА}

\author{
Yuri Shepel ${ }^{1}$ \\ Olena Fedina ${ }^{2}$
}

DOI: https://doi.org/10.30525/978-9934-26-051-3-10

\begin{abstract}
The language is able to provide information about the qualitative and quantitative characteristics of the objective world in the conceptual system of a person. Within the framework of the field approach, which is used in the work, the meanings that construct the associative component of the concept are analyzed, since it is isomorphic to the lexicalsemantic field that represents it. The section presents the features of the inner world of a person through the analysis of the semantics of phraseological units. The relevance of the study is due to the need to study and describe the concept of a person in phraseology from the standpoint of the anthropological paradigm of linguistics. The subject of scientific analysis is the concept of a person, verbalized in the phraseology of the Russian language. The methodological basis of the work is an anthropocentric approach to the study of the content of linguistic phenomena, which necessitates the use of linguistic, cognitive and culturological methods of analyzing linguistic material in the dialectical unity. The authors set a goal - to describe the characterological features of the concept under study, the way of their manifestation as a means of reflecting the image of a person. It is shown that anthropocentrically nominative phraseological units in pragmatic terms act as semiotic regulators, fixing and reflecting in a figurative-symbolic form a model of human behavior, features of his appearance, character

\footnotetext{
${ }^{1}$ Doctor of Science (Philology), Full Professor,

Academician of the National Academy of Sciences of Higher Education of Ukraine,

Oles Honchar Dnipro National University, Ukraine

${ }^{2}$ Candidate of Sciences (Philology), Lecturer,

(C) Yuri Shepel, Olena Fedina
}

Industrial College of the Ukrainian State University of Chemical Technology, Ukraine
\end{abstract}


traits, traditions and customs of the people, a system of assessments of everything that forms the phraseological space of a person. The process of phraseological nomination of a person is based on phraseological rethinking. One of the most important characteristics of a phraseological unit for designating a person is semantic motivation, since phraseological units are linguistic signs formed as a result of a secondary nomination. As a mental phenomenon, language is assigned the role of one of the methods of coding known forms of cognition: both sensory (perception, sensation, representation) and rational (judgments, concepts, conclusions). It is shown that the mentality of the people is actualized in the most significant linguistic concepts of culture, the main task of which is to reflect national priorities and ideals. The content of the concept of a person includes not only actual perceived semantic components associated with a word (phraseological unit), but also signs that reflect the general information base about a person, his knowledge of an object or phenomenon. It is brought that the phraseological concept is a discrete, semantic volumetric unit of thinking or memory, which reflects the culture of the people, and the meaning is part of the concept; concept refers to cognitive consciousness, and meanings refer to linguistic consciousness.

\section{1. Вступ}

Лінгвістичний процес опису концептів переважно грунтується на матеріалі лексичних одиниць і паремій, а фразеологізми залишаються поза увагою та здебільшого не є об'єктом досліджень. Під час найменування явищ дійсності, фразеологічні одиниці, які відображають оцінку й емоційне ставлення носія мови, фіксують найбільшу кількість національно-культурної інформації: менталітет народу, спосіб його життя, звичаї, вірування, національні стереотипи та еталони, стосунки всередині соціуму, історичні події, усе те, що є предметом національної культури й бере участь у формуванні концептуальної картини світу, яка, матеріалізуючись у мові, відображає мовну картину світу.

Суттєвим доповненням до антропоцентричного підходу у вивченні мовних явищ, пов'язаних із репрезентацією людини в мові i, передусім, в обраному фразеологічному матеріалі, у дисертації частково є аксіологічний підхід, який передбачає визнання того, що людина постає цінністю як така, цінною для навколишніх та для суспільства. 
Мета дослідження - виявити характерологічні ознаки досліджуваного концепту, способів їхньої маніфестації як засобів віддзеркалення образу людини.

Представлена мета передбачає виконання таких завдань:

- обгрунтувати специфіку антропоцентричного принципу сучасних досліджень у галузі фразеології;

- розглянути поняття людина як компонент лінгвістичної картини світу з урахуванням особливостей відображення «людського» коду в російській мові;

- описати семантичні особливості фразеологізмів на позначення людини в російській мові з урахуванням впливу культурно-історичних чинників.

Методологійною базою роботи $є$ антропоцентричний підхід до дослідження змісту мовних явищ, що зумовлює необхідність використання в діалектичній єдності лінгвістичних, когнітивних і культурологічних методів аналізу мовного матеріалу. Отже, методологійним підгрунтям для дослідження стали ідеї, розроблені в працях Ю. М. Караулова, С. Д. Кацнельсона, В. І. Постолової, Н. В. Сабурової, Ю. С. Степанова, В. М. Телії, Г. С. Щура та ін.

Суттєвим доповненням до антропоцентричного підходу у вивченні мовних явищ, пов'язаних із репрезентацією людини в мові i, передусім, в обраному фразеологічному матеріалі, є аксіологічний підхід, який передбачає визнання того, що людина постає цінністю як така, цінною для навколишніх та для суспільства. Смисл аксіологічного підходу розкриваємо через систему аксіологічних принципів, до яких уналежнюємо:

- рівноправність усіх філософських поглядів у межах єдиної гуманістичної системи цінностей (зі збереженням різноманітності їхніх культурних і етнічних особливостей);

- рівнозначність традицій і творчості, визнання необхідності вивчення і використання вчення минулого та можливості відкриття в теперішньому та майбутньому;

- екзистенціальну рівність людей, соціокультурний прагматизм замість суперечок про підгрунтя цінностей.

Отак, аксіологічний аспект є закономірним продовженням і доповненням антропоцентричного. 


\section{2. Фразеологія як репрезентація етнокультурної пам'яті народу}

Російська культура, як і будь-яка інша, сотні років транслює світовій цивілізації ідеали духовності, взаємодопомоги, співчуття, милосердя тощо, які відображено в національній мові та іiі фразеологічному фонді, зокрема, який як етногенетичний код зберігає спадковість і константність національного світобачення та самоідентичності, віддзеркалює найважливіші життєві принципи, пор.: На Бога надейся, а сам не плошай; Всякое даяние - благо; Грех не смех, когда придёт смерть; Беда не страшит, а путь укажет; Вся семья вместе, так и душа на месте тощо [6]. Картина російського світу містить різні фрагменти мовних полів, найважливішим з яких для репрезентації його специфіки потрібно визнати фразеосемантичне поле (ФСП). Для нашого дослідження найбільший інтерес представляє ФСП як один 3 різновидів семантичного поля. Згідно з сучасними поглядами фразеологічний фонд мови, подібно лексичному фонду, являє собою певну мовну систему, члени якої вступають між собою в різні, в тому числі і семантичні, відношення. Вивчення й опис цих відношень представляє великий теоретичний і практичний інтерес, оскільки це одне із завдань фразеології як самостійної галузі мовознавства. Семантика фразеологічних одиниць - явище набагато складніше і більш специфічне за семантику лексичних одиниць, що обумовлює необхідність вивчення системних зв'язків, чому, в свою чергу, сприяє теорія семантичних полів, яку останнім часом інтенсивно поглиблюють. Фразеосемантичне поле (ФСП) розуміємо як структурну організацію сукупності фразеологічних одиниць, які знаходяться в певних системних відношеннях і об’єднуються спільністю семантичної теми і спільністю вираження одного поняття (у нашій роботі - це макросистема концепту людина). Необхідними конституентами в складі поля виступають ядро, яке ідентифікує значення польового освіти, центр і периферія. Мінімальною складової змісту фразеосемантических поля $є$ фразеосемема, що визначає план змісту фразеологічної одиниці.

Звертаючись до сучасних досліджень 3 фразеології в розрізі національно-культурної специфіки, визнаємо очевидним їхній симбіоз з ідеями лінгвокультурології, зокрема щодо поняття «фразеологічна картина світу». 3 цих позицій фразеологічна картина світу виглядає як апріор- 
но-аксіоматична категорія. Тож термін «фразеологічна картина світу» часто вживають на позначення усіх фразеологізмів у системі мови.

Фразеологічна картина світу (далі - ФКС) являє собою вербалізований результат процесу мислення та пов'язана з категоризацією й фразеологічною концептуалізацією дійсності, з фіксацією та поданням в образній формі побуту, традицій, звичаїв і ментальності народу. ФКС - це унікальний семіотико-ментальний конструкт, мовне відображення життя народу, його національного духу, етнічної самосвідомості, що представлені та акумульовані в семантиці фразем, паремій та інших стійких виразів. Під час фразеологічної концептуалізації російської дійсності експлікується феномен вторинної антропологізації мови, пов'язаний із впливом різних картин світу особистості - наївно-побутової, філософської, архетипної, релігійної, міфологічної, художньо-поетичної, наукової, психологічної, конфесійної, етноконфесійної тощо [19, с. 106].

Фразеологія $є$ етноспецифічним когнітивно-дискурсивним конструктом, а ії̈ одиниці, як комунікативно-динамічний засіб дискурсивної практики членів соціуму, висловлюють та відбивають етнокультурні та духовно-конфесійні особливості його історичного і цивілізаційного розвитку.

Відповідно до наших спостережень, головним, ключовим фразеоконцептом російської ФКС і російської лінвокультури виступає концепт людина, у якому відображені найважливіші уявлення російського народу про людину як члена соціуму, в оцінному ключі представлені лінгвістичні характеристики всіх іпостасей буття людини, починаючи з зовнішнього вигляду до специфіки поведінки в тих чи тих ситуаціях.

Цікавою й складною виявляється етимологія лексеми «людина». Якщо виходити із семантико-дериваційного аналізу, то бачимо, що слово *čelovekъ, як протилежне за кількісною семантикою слову *ludьje, висловлює когнітивну ознаку одиничності, тобто «хтось (один) 3 людей». Іменна семантика «людина» і займенники (неозначені) смислову аспектність «хтось, хто-небудь» нерідко репрезентують ідентичне - у формальному плані - значення. Усі ці значення дають підставу припустити займенниковий параметр праслов'янської одиниці čelovekъ, що дає змогу встановити певну кореляцію 3 *koli-vekъ (регіонально слов'янською формою) - «хто-небудь», перша основа якої є ранньою формою, яка перетворилася в праслов'янській мові в *čele-, *čeli-. 
Друга ж основа інтерпретується як «вік», «сила». На підставі існуючих етимологічних даних, поняття «людина» здебільшого трактують через такі когнітивні класифікатори: людина як «дитя роду», як «той, хто має силу» і як «хтось», що означає будь-кого, кожного представника роду. Різні лексикографічні джерела (тлумачні та енциклопедичні) подають такі базові вербальні ідентифікатори зазначеного поняття: людина це: 1) «створіння»; 2) «істота»; 3) «суб'єкт»; 4) «система». Під час дослідження фразеологічного поля / простору «людина» виявлено факт, який свідчить про те, що семантико-смислова і когнітивно-аксіологічна системність антропокваліфікативних ФО формується головним чином з емоцій, культурних настанов, оцінного компонента. У структурі кожного концепту-поняття можна виокремити його складові - образну (сукупність уявлень, образів, символів), поняттєву (мовна репрезентація за допомогою простих і складних номінацій денотатного ряду i/або класу), аксіологічну (семіотична репрезентація етнокультурних духовних, релігійно-конфесійних, моральних, соціально-історичних, традиційних ціннісних домінант). Максимально репрезентативними мовними одиницями в такому аспекті $є$ фразеологізми та паремії, які можна інтерпретувати як вербалізовану мовну та ментальну свідомість багатьох поколінь носіїв національної мови, що зафіксували в образно-оцінній формі картину світу й образ людини як виразника національного духу [23, с. 64].

Фразеологічна картина світу є вербалізованим результатом когнітивного мислення, яке пов'язане з категоризацією та фразеологічною концептуалізацією дійсності, з фіксацією та зображенням в образній формі побуту, традицій, звичаїв і ментальності народу. ФКС - це унікальний семіотико-ментальний конструкт мовного віддзеркалення життя народу, його національного духу, етнічної самосвідомості, які представлені й акумульовані в семантиці фразем, паремій та інших стійких виразів.

У процесі фразеологічної концептуалізації російської дійсності визначаємо есплікуцію феномену вторинної антропологізації мови, що пов'язана з впливом різних картин світу людини - наївно-побутової, філософської, архетипної, релігійної, міфологічної, художньо-поетичної, наукової, психологічної, конфесійної, етноконфесійної та ін.

Максимально репрезентативними мовними одиницями в такому аспекті є фразеологізми та паремії, які інтерпретуємо як вербалізовану 
мовну та ментальну свідомість багатьох поколінь носіїв національної мови, що зафіксували в образно-оцінній формі картину світу й образ людини як виразника національного духу.

\section{3. Загальна характеристика фразеосемантичного поля людина}

Мовна картина російського світу містить різні фрагменти мовних полів, найважливішим з яких для репрезентації його специфіки визнаємо фразеологічне (фразеосемантичне) поле (ФСП).

3 одного боку, ФСП належить до універсальних у системі будь-якої мови, а його члени активно вплітаються в процес ідіоматизації, а $з$ другого - склад, семантика (а також іiї концептуально-прагматична складова) членів ФСП багато в чому визначаються екстралінгвістичними факторами, зокрема, культурно-історичними особливостями в житті російського етносу. «Польові» дослідження фразеології припадають на к. XX - поч. XXI ст.

У мовознавстві науковці визначають декілька видів полів: лексичне, семантичне, асоціативне та функційно-семантичне. У зв'язку з інтенсивним розвитком польового підходу під час дослідження мови останнім часом відтінилися інші види полів, як-от: комплексні, фразеосемантичні. Механізми концептуалізації та вербалізації пояснює теорія прототипів С. Рош, фреймова семантика Ч. Філлмора, теорія метафори Дж. Лакоффа й М. Джонсона, М. Тернера, Ж. Фоконьє та ін.

Аспекти структурно-семантичного моделювання фразеології сфери людина загалом пов'язані з виокремленням чотирьох структурно-семантичних моделей: «Людина + оцінно-кваліфікуюча ознака», «Оцінно-кваліфікуюча ознака», «Процесуально-оцінна ознака», «Категорійно-оцінна ознака», які моделюються з урахуванням безпосередньо складових компонентів фразеологічного значення.

Семантичне поле (СП) концепту людина, за даними лексикографічних джерел (семантичні, ідеографічні, тематичні й тлумачні словники), надзвичайно різноманітне за конкретним значенням своїх компонентів і складне в організаційному плані, оскільки ситуативно воно пов'язане 3 кількома взаємопов'язаними й типовими семантичними сферами та понятійними галузями: 
- фізіологія людини (пов'язане з необхідністю задовольняти потреби живого організму в чомусь);

- соціальні та культурні характеристики, що охоплюють, по-перше, творчу (трудову, побутову і професійну) діяльність і визначаються соціально-економічними, культурно-історичними особливостями розвитку етносу;

- соціальні й міжособистісні стосунки, комунікація, соціально-економічне становище людини:

- стану, пов'язаному з потребою в чомусь; стереотипи поведінки узагальнене уявлення про поведінку людини та ії манери;

- мовленнєва поведінка як сукупність мовних вчинків.

Різні групи та підгрупи СП людина відіграють різну роль у формуванні російської фразеології, що до певної міри пов'язано з важливістю різних сторін семантичної сфери «людина» в російській мовній картині світу.

Опрацьовування особливостей мови виразно відбиває підвищену увагу лінгвістів до структури лінгвістичних полів ${ }^{1}$. Проте класифікація мовних полів у сучасній лінгвістиці та їх визначення залишається питанням відкритим, без чіткої відповіді (В. Ройнінг [16], Г. Іпсен [8], Й. Трір [26], Ф. П. Філін [29], С. Д. Кацнельсон [10], Н. В. Уфімцева [27], Ю. М. Караулов [9], Н. В. Ротова [17], Л. Л. Васильєв [5], Н. І. Долгих [7] та ін.).

У словнику «Мовознавство. Великий енциклопедичний словник» (за редакцією В. М. Ярцевої) поле визначають як «сукупність мовних (переважно лексичних) одиниць, які об'єднані за змістом (іноді навіть за формальними показниками) і відображають понятійну, предметну чи функційну схожість позначуваних явищ» [34, с. 108].

Характеризуючи поняття «поле» Г. С. Щур зважає на факт взаємодії між виразними елементами та інтерпретує таку взаємодію, як «атракція», що є визначальним не для всіх елементів, оскільки в мові існує декілька типів взаємодії [33, с. 254]. Тому полем він називає певні інваріантні та функційно-інваріантні групи слів [33, с. 97].

У лінгвістичних енциклопедичних виданнях «поле» трактують як «сукупність мовних одиниць, які об'єднані цілісністю змісту явищ» [25, с. $380-381]$.

${ }^{1}$ Одними 3 перших такі поняття, як «поле», «типологія семантичних полів», ужили у своїх розвідках науковці Г. Іпсен [8], Й. Трір [26]. 
Лінгвісти виокремлюють декілька видів полів: лексичне, семантичне, асоціативне та функційно-семантичне [4, с. 11-12]. У зв'язку з інтенсивним розвитком польового підходу під час дослідження мови останнім часом відтінилися інші види полів, як-от: комплексні, фразеосемантичні.

Термін «поле» зазвичай відносять до широких груп слів. Різні науковці підходили до вивчення системності лексики по-різному і визначали поля, спираючись на різні точки зору [14, с. 47-52].

Поля за М. М. Покровським. Науковець одним із перших розглянув завдання системного вивчення лексики (починаючи з 1890-х років), та виокремив «семантичні поля», розглядати які, на його думку, потрібно відповідно до трьох критеріїв [цит. за: 14, с. 47-48]:

1) тематична група - слова належать до «одного кола уявлень»,

2) синонімія;

3) морфологічні зв'язки (наприклад, слова однієї частини мови, одного словотвірного типу).

Зазначений тип полів залишається одним з актуальних об'єктів лексико-семантичних досліджень, оскільки на таку концепцію спирається теорія поля «лінгвістичного», яка була запропонована такими науковцями, як С. К. Шаумян, П. А. Соболєва та Ю. О. Шепель [20; 21; 30; 31 , с. 75-80; 32, с. 19-43].

Поля за Й. Тріром. Й. Трір ієрархічно розмежовує всю глобальну систему мови на два паралельних типи полів: понятійні та словесні, кожне з яких, відповідно, розподіляє на елементарні одиниці - поняття та слова, при цьому складові компоненти словесного поля, подібно до камінців мозаїки, наповнюють сферу відповідного понятійного поля [26, с. 106]. Й. Трір запропонував розподілити поля на лексичні й понятійні. Лексичне поле, на думку дослідника, утворюється за допомогою будь-якого слова (відповідає семантичній структурі слова й асоціатам, зокрема, словотвірним). Лексичне поле - частина понятійного («наповнює його частково») [26, с. 199].

Поля за В. О. Порцигом. Науковець виводить семантичне поле, спираючись на інші принципи: обирає вихідною точкою мовні факти та говорить про «елементарні семантичні поля», ядром яких є дієслово, або прикметник, оскільки зазвичай ці класи слів можуть виконувати функцію присудка. У другій половині ХХ ст. такі поля не лише були 
основою дослідження глибинної семантичної структури мови, але й стали прототипами асоціативних полів [цит. за: 14, с. 49].

Останнім часом, спираючись на думку В. М. Телії [24] про те, що $Ф О$ - це бути засобом вторинної номінації, що «в образній основі фразеологізмів різних типів найбільш конденсовано втілюються характерні риси світосприйняття лінгвокультурної спільноти», багато лінгвістів [див.: 10] дотримуються до думки, що семасіологічні та ономасіологічні дослідження «демонструють тенденції до редукції в розрізненні цих понять, що знаходить своє пояснення в завданнях дослідження: акцентувати увагу на семасіологічній та ономасіологічній специфіці мовного образу, а не на прагматичному ефекті, який він виконує» [12]. Поняття внутрішньої форми (мовного образу) стали доповнювати поняттям лінгвокультуреми, що у загальному вигляді позначається формулою «внутрішня форма = образ (+ лінгвокультурема)» [18].

Щодо лексики, семантичним полем зазвичай називають об'єднання слів на основі їхньої семантичної спільності. Віднесення фразеологізмів до того чи того семантичного поля грунтується насамперед на виокремленні найбільш значущих компонентів у змісті ФО (ідея «вибраної» семи, iї нетривіальность), тобто враховується «вага» - семантична цінність співпадаючих і різних компонентів [3]. На цій підставі в нашому дослідженні, наприклад, ідіому взять быка за рога - [дія] (Начинать действовать энергично, решительно, сразу и с самого важного в трудном деле), можемо розглядати у двох семантичних полях 1) ШВИДКІСТЬ, 2) ШВИДКІСТЬ і РІШУЧІСТЬ, ЗАВЗЯТІСТЬ, оскільки в одних контекстах у фокусі уваги буде сема «відразу, швидко», а в інших - «рішучість». Додамо, що, орієнтуючись на «Словарь-тезаурус современной русской идиоматики: около 8000 идиом современного русского языка» [35], ми відносимо до семантичного поля термінальні таксони, тобто найменші одиниці семантичного членування фразеології. А загальну одиницю (категорію) такого членування ми трактуємо фразеосемантичним полем. Наприклад, семантична область РУХ (людини) може бути представлена сьома семантичними полями: ШВИДКИЙ РУХ (дать волю ногам, бежать со всех ног, сорваться с места, броситься стремглав, показать пятки та ін.), де образні номени репрезентовані різними комбінаціями, як-от: інтенсивність, раптовість, моментальність, що зумовлено амбівалентністю семантичної 
структури цих ідіоматичних і перифрастичних зворотів; ПОВІЛЬНИЙ РУХ (черепашьим тагом, нога за ногу), РУХ ДО ОБ'ЄКТА (наступать на пятки, наступать на хвост, висеть на хвосте, на кривой козе не подъедешь) зі значенням близькості, сукупності; РУХ У ЗВОРОТНОМУ НАПРЯМКУ (дать задний ход, поврнуть оглобли назад, от ворот поворот); ХАОТИЧНИЙ РУХ (Как белка в колесе, виться вьюном, как рыба на сковороде) з визначенням непрямого, безперервного, невизначеного руху з негативною конотацією, ПОЯВА (как снег на голову), де значення передається прислівниковими фраземами з компонентом словно, как; ВТЕЧА (как ветром сдуло, искать ветра в поле, только и видели), де виокремлюється низка синонімічних варіантів дієслівних та від адвербіальних сполук зі значенням раптового руху, тощо.

У сучасній лінгвістиці наявні різні точки зору щодо польової структури. Ю. С. Степанов, визначаючи співвідношення понять «структура» й «система» говорить про ядро та периферію мовної системи [22, с. 61]. Лінгвісти по-різному вивчають ці поняття, проте можна впевнено стверджувати, що ядро формується навколо компонента-домінанти. До периферії належать віддалені одиниці. Периферійні одиниці можуть вступати в контакт з іншими семантичними полями, утворюючи лексико-семантичну неперервність мовної системи. Перехід від ядра до периферії здійснюється поступово, тому чіткої межі між ядром і периферією не простежується. Усі лексичні одиниці віддалені на різну відстань від ядра, що дає змогу вченим говорити про ближню та дальню периферію [11].

Отже, поля які визначаються на основі певних ознак, є системними формуваннями з притаманними їм відношеннями та зв'язками для будь-якої системи й водночас своїми специфічними рисами. Однією 3 рис поля є можливість об'єднувати у своєму складі гетерогенні мовні засоби, які належать до різних класів або мовних рівнів. Від ядра до периферії рух відбувається поступово, позначаються певні периферійні зони, по-різному десантовані від ядра. У своєму складі поле спроможне поєднувати кілька мікрополів, яким властива відносна самостійність [1, с. 42].

Думки дослідників щодо основ моделювання полів та їх ідентифікаторів, характеру відношень між одиницями (конституентами) семантичного поля не співпадають [13]. 
Одиниці семантичного поля об'єднуються загальним (інваріантним) значенням. Лексичні одиниці належать до семантичних полів на підставі того, що в них є спільна сема, наприклад: особняк, дом, квартира, комната, хижина, дворец тощо - належать до семантичного поля «найменування житла», оскільки об'єднуються архісемою «замкнутий простір, місце для проживання людини» [2; 15].

Семантичне поле містить низку ознак:

1) зв'язок слів або їхніх окремих значень;

2) системний характер цих зв'язків;

3) взаємозалежність лексичних одиниць;

4) відносна автономність поля;

5) безперервність смислового простору;

6) психологічна реальність для посереднього носія мови.

Описуючи поле, важливо виокремити елементи ядра та периферії й визначити, з якими полями можливий перетин.

\section{4. Висновки}

Фразеологічна одиниця як спосіб фіксації поняття в мові спочатку має у своєму розпорядженні групу смислових орієнтацій (пресупозицій), що реалізуються в мовленнєвій діяльності. Залежно від намірів суб'єкта й залежно від ситуації відбувається реалізація тих чи тих пресупозицій. Установлюються нові понятійні та семантичні зв'язки між мовними знаками.

Слова-компоненти у складі фразеологічної одиниці сигналізують про «початковий денотат», який був певним чином інтерпретований суб'єктом, що й слугує основою формування мовного значення стійкого сполучення слів. Звідси випливає, що фразеологічна одиниця - це застиглий у мові досвід пізнання народу.

Оскільки етномова нерозривно пов'язана з етнокультурою, що виявляється в постійному вливанні культурних кодів в етномову, а саме у сфери образної лексики, фразеології та пареміології, фразеологічний фонд на образному рівні $є$ одним із природних втілень низки культурних кодів, субкодів і фрагментів.

Слово називає, а ФО виражає ставлення. Причому прагматичний аспект ФО виражений набагато сильніше, ніж у лексичної одиниці, навіть якщо вона вживається в переносному образному значенні. Прагматич- 
ний компонент значення ФО превалює над денотатним, тому специфічність фразеологічного значення полягає, перш за все, в ідеографічній націленості на експресивно-емоційні сфери найменування реалій.

Конотативний макрокомпонент семантичної структури ФО вміщує семи, які позначають ціннісно-характеризуючі та емоційно-оцінювальні сприйняття людиною навколишнього світу.

Фундаментом формування конотативної семантики фразеологізму $€$ образність, яка виявляється як суміщення двох картин, викликаних первинною та вторинною номінаціями.

Кожний фразеологізм виконує певну стилістичну функцію, яка залежить від контексту, стилю автора, характеру всього повідомлення.

Фразеологізми з назвами людей у лексичному наповненні відзначаються великим діапазоном сфер використання. Спостереження говорять про різноплановість характеристик, кваліфікованих названими ФО. Людина як еталон освоєння різних категорій буття дала поштовх до виникнення фразеологізмів, що функціонують для називання фрагментів як матеріального, так і нематеріального світу.

Проте людина першочергово усвідомлюється як істота біологічна, що відповідним чином відбивається й у семантиці фразеологічних мовних засобів. Зокрема, виокремлено ФО, у значеннєвій структурі яких домінантними є семи, що маніфестують гаму емоцій і почуттів (від захоплення й до відрази) та актуалізують модальну оцінку: батюшки, твою мать, черт его знает, чертово отродье, чертова баба, матерь божья, аллилуйя тощо.

Серед аспектів вияву людської діяльності в мові є:

1) формування картини світу в мові та створення мовного інвентарю;

2) породження мовлення;

3) роль людини у процесі комунікації.

Пошук галузі компетенції мовної особистості з метою визначення універсалій вилився у необхідність враховувати таку собі мовну гру, яка з позиції логіко-семантичних структур, а також з позицій докультурологічних реалій підіймається саме як певний універсальний фрейм.

Взаємодія внутрішнього і зовнішнього контекстів параметрів людини у кожному випадку утворює конкретну картину світу, створену саме цією людиною, саме з даними характеристиками, саме в цьому місці і саме у цей час. Під час дослідження виявлено таке співвідно- 
шення: людина та іiї мова - вживання мови людиною (конструювання та реконструкція нею слів і ФО та їхніх значень), а також мова та картина світу - співвідношення мовної і концептуальної картини світу.

Семантична структура фразеологізмів унікальна та складна. Фразеологічне значення - явище динамічне, викликане особливою взаємодією форми та змісту, що призводить до виникнення абстрактного значення. Особливістю фразеологічного значення $\epsilon$ семантична деталізованість і стилістична маркованість ФО як наслідок сполучення смислів конституентів, їхня поліденотативність, здатність називати різні фрагменти дійсності. Фразеологічне значення складається з упорядкованих сем, співвідносних з певними якостями та явищами дійсності. Значення ФО образно мотивоване, більш насичене нюансами, певними деталями, ніж значення окремого слова.

Прийом структурно-семантичного (польового) дослідження лінгвістичного континууму в загальному вигляді підпорядковується таким чинникам: класифікація повинна спиратися на повну, логічно зумовлену схему, яка буде підкреслювати існування цілісної «тканини» мовної картини світу, у якій кожна одиниця буде займати відповідне місце вираження; за основну одиницю ідеографічної класифікації обирається семантичний клас, ознаки якого нейтралізуються в певних контекстах; відношення між класами відображаються схемою класифікації понять; класифікація фразеології / лексики оперує словами-поняттями, а не багатозначними словами (висловлюваннями); під час співвідношення слова до певного семантичного класу потрібно звертати увагу на явище гіперболізації значень слів, наявність «дифузності» в його межах; у виділених тематичних групах слів.

Теорія поля в лінгвістиці є прикладом системного підходу до вивчення екстралінгвістичної природи мовної дійсності. Польовий метод дослідження дає змогу точно й повно представити фактичний матеріал як однієї, так і різних мов в сукупності зав'язків і відношень, дає можливість побачити об'єктивну картину семантичного простору мови і смислових асоціацій.

Перспектива подалышого дослідження. Дослідження антропоцентричної фразеології в лінгвокультурологічному, когнітивному й семантичному аспектах не лише доповнює та збагачує фразеологію новими знаннями, але й окреслює перспективи подальших досліджень, 
як-от: докладне дослідження характерних для образу-концепту людина дискурсів та пов'язаних з ними стратегій і тактик мовної поведінки комунікантів, усебічне вивчення фразеологізмів у дискурсивно-прагматичному плані, у питанні перетину семантичних фразеологічних полів, місця фразеології в афористичній картині світу.

\section{Список літератури:}

1. Адмони В. Г. (1964). Основы теории грамматики. Москва-Ленинград : Наука: 104.

2. Амичба Д. П. (2006). К вопросу «фразеология в контексте культур». Известия ТулГУ. Серия. Язык и литература в мировом сообществе. Вып. 9. Лингвокультурологические аспекты изучения русского языка. Тула : Изд-во ТулГУ: 3-8.

3. Астахова Я. А. (2013). К вопросу о понимании коннотации в лингвокультурологии. Вестник Орловского государственного университета. Серия : Новые гуманитарные исследования: 182-187.

4. Березан О. В. (2000). Посібник для вчителів мови. Київ: 303.

5. Васильев Л. Л. (1962). Тайные представления человеческой психики. Москва: 340.

6. Гончарова Н. Н. (2012). Языковая картина мира как объект лингвистического описания. Известия Тульского государственного университета. Гуманитарные науки. Тула : Изд-во ТулГУ. Выпуск 2: 53-59.

7. Долгих Н. Г. (2011). Теория семантического поля на современном этапе. Воронеж : Научная книга: 360.

8. Іпсен Г. (1900). Мова як основа суспільства. Осло: 240.

9. Караулов Ю. М. (2009). Лингвокультурологическое сознание русской языковой личности. Моделирование положения и функционирования. Москва: 580.

10. Кацнельсон С. Д. (2001). Категории языка и речи. Москва: 265.

11. Кононенко I. В. (1996). Національно-мовна картина світу: зіставний аспект (на мат-лі укр. та рос. мов). Мовознавство. Київ: 36-46.

12. Корнилов О. А. (1999). Языковые картины мира как производные национальных менталитетов. Москва : Изд-во МГУ: 341.

13. Новиков А. О. (2008). Современный русский язык. Харьков: 56.

14. Постовалова В. И. (1988). Картина мира в жизнедеятельности человека. Роль человеческого фактора в языке: Язык и картина мира. Москва : Наука: 212.

15. Радзиєвська Т. В. (2010). Нариси з концептуального аналізу та лінгвістики тексту: Текст - соціум - культура - мовна особистість. Київ : ДП «Інформ.аналіт. агентство»: 491.

16. Ройнинг В. (1986). Иностранная филология 20 века. Москва: 203.

17. Ротова Н. В. (2014). Роль власної назви в характеротворенні та формуванні імпліцитної оцінки зображуваних подій. Харьков: 160. 
18. Сабурова Н. В. (2016). Жизнь языка и культуры в социуме. КемеровоЯлта : КГУ: 268.

19. Селіванова О. О. (2012). Фразеологія у дзеркалі етносвідомості. Черкаси: 308.

20. Соболева П. А. (1984). Моделирование сложных прилагательных. Проблемы структурной лингвистики. 1982. Москва : Наука: 67-81.

21. Соболева П. А. (1983). Трансформационные поля аппликативной порождающей грамматики и моделирование сложных слов. Проблемы структурной лингвистики. 1981. Москва : Наука: 83-95.

22. Степанов Ю. С. (2007). Концепты. Тонкая пленка цивилизации. Москва : Языки славянских культур: 248.

23. Телия В. Н. (1977). Фактор культуры и возрождение фразеологизмов. Москва: 260.

24. Телия В. Н. (1999). Первоочередные задачи и методологические проблемы исследования фразеологического состава языка в контексте культуры. Фразеология в контексте культуры. Москва : Языки русской культуры: 203-211.

25. Тернер М. (1998). Избранные труды. Пособие для студентов. Прингстон: 298.

26. Трир Й. (1990). Избранные труды. Москва: 210.

27. Уфимцева Н. В. (2012). Этнический язык в условиях культурной и языковой полифонии. Филология и культура. Казань: 124-135.

28. Федіна О. В. (2020). Фразеосемантичне поле концепту людина в російській мові: функційно-прагматичний аспект : дис. канд. філол. н. : 10.02.02. Дніпро: 235.

29. Филин Ф. П. (1970). Очерки по истории языкознания до XIV столетия. Вопросы языкознания. Москва : Наука: 77-85.

30. Шепель Ю. А. (2010). К вопросу о национально-культурной специфике речевой деятельности в современной лингвистике. Наукові записки Луганського начіонального університету. Вип. IX. Серія «Філологічні науки»: Зб. наук. праць [Пред'явлення світу в гуманітарних дискурсах XXI століття]. Луганський наи. ун-т ім. Тараса Шевченка. Луганськ : Вид-во ДЗ «ЛНУ імені Тараса Шевченка»: 112-117.

31. Шепель Ю. А. (2012). Словообразовательный ряд как комплексная единица словообразования (КЕС). Н. М. Шанский - теоретик, практик, педагог : Материалы мемориальной юбилейной международной научно-практической конференции. 22 ноября 2012 г. Симферополь : Дом Писателей им. Домбровского: 75-80.

32. Шепель Ю. А. (2011). Формирование системы культурных концептов в рамках когнитивных возможностей личности. Східнослов'янська філологія: зб. наукових праць. Горлівський держ. пед. ін-т іноземних мов; Донецький нац. ун-т. Редкол.: С. О. Кочетова та інші. Вип. 20. Мовознавство. Горлівка : Видавництво ГДПІІМ: 19-43.

33. Щур Г. С. (1974). О типах лексических ассоциаций в языке. Москва: 154. 34. Ярцева Л. И. (1990). Человек телесный во фразеологии. Киев: 203.

35. Словари и энциклопедии на Академике. URL: dic.academic.ru 


\section{References:}

1. Admony V. Gh. (1964). Osnovy teorii grammatiki [Fundamentals of the theory of grammar]. Moscow-Lenynghrad: Nauka: 104. (in Russian)

2. Amichba D. P. (2006). K voprosu «frazeologhyja v kontekste kul'tur [To the question «phraseology in the context of cultures]. Yzvestyja TulGhU. Seryja. Jazyk i lyteratura $v$ myrovom soobshhestve, vol. 9. Lynghvokul'turologicheskije aspekty izuchenija russkogo jazyka: 3-8.

3. Astakhova Ja. A. (2013). K voprosu o ponymanyy konnotacyy v lynghvokul'turologhii [To the question of understanding the connotation in linguistic and cultural]. Vestnyk Orlovskogho ghosudarstvennogho unyversyteta. Seryja: Novye ghumanytarnye yssledovanyja: 182-187.

4. Berezan O. V. (2000). Posibnyk dlja vchyteliv movy [A guide for language teachers]. Kyiv: 303. (in Ukrainian)

5. Vasylj'ev L. L. (1962). Tajnye predstavlenyja chelovecheskoj psykhyky [Secret representations of the human psyche]. Moscow: 340. (in Russian)

6. Ghoncharova N. N. (2012). Jazykovaja kartyna myra kak ob'ekt lynghvystycheskogho opysanyja [Linguistic picture of the world as an object of linguistic description]. Yzvestyja Tuljskogho ghosudarstvennogho unyversyteta. Ghumanytarnye nauky, vol. 2: 53-59.

7. Dolghykh N. Gh. (2011). Teorija semantycheskogho polja na sovremennom etape [The theory of the semantic field at the present stage]. Voronezh: Nauchnaja knygha: 360. (in Russian)

8. Ipsen Gh. (1900). Mova jak osnova suspiljstva [Language as the basis of society]. Oslo: 240. (in Ukrainian)

9. Karaulov Yu. N. (2009). Lynghvokul'turologhycheskoye soznanie russkoj jazykovoj lichnosti. Modelyrovanie polozhenija i funkcyonyrovanyja [Linguoculturological consciousness of the Russian linguistic personality. Modeling position and functioning]. Moscow: 580. (in Russian)

10. Kacneljson S. D. (2001). Kateghorii jazyka i rechy [Categories of language and speech]. Moscow: 265. (in Russian)

11. Kononenko I. V. (1996). Nacionaljno-movna kartyna svitu: zistavnyj aspekt (na mat-li ukr. ta ros. mov) [National-linguistic picture of the world: comparative aspect (on materials of Ukrainian and Russian languages)]. Movoznavstvo. Kyiv: $36-46$.

12. Kornylov O. A. (1999). Jazykovye kartiny myra kak proizvodnye nacyonaljnykh mentalytetov [Linguistic pictures of the world as derivatives of national mentality]. Moscow: Yzd-vo MGhU: 341. (in Russian)

13. Novykov A. O. (2008). Sovremennyj russkij jazyk [Modern Russian language]. Kharjkov: 56. (in Ukrainian)

14. Postovalova V. Y. (1988). Kartyna myra v zhyznedejateljnosty cheloveka. Rolj chelovecheskogho faktora $v$ jazyke: Jazyk i kartyna myra [Picture of the world in human life. The role of the human factor in language: Language and worldview]. Moscow: Nauka: 212. (in Russian)

15. Radzyjevsjka T. V. (2010). Narysy z konceptualjnogho analizu ta linghvistyky tekstu: Tekst - socium - kul'tura - movna osobystist' [Essays on conceptual 
analysis and linguistics of the text: Text - society - culture - linguistic personality]. Kyiv: DP «Inform.-analit. aghentstvo»: 491. (in Ukrainian)

16. Rojnyngh V. (1986). Ynostrannaja fylologhyja XX veka [Foreign philology of the 20th century]. Moscow: 203. (in Russian)

17. Rotova N. V. (2014). Rol' vlasnoji nazvy v kharakterotvorenni ta formuvanni implicytnoji ocinky zobrazhuvanykh podij [The role of one's own name in the characterization and formation of an implicit assessment of the depicted events]. Kharkiv: 160. (in Ukrainian)

18. Saburova N. V. (2016). Zhyzn' jazyka i kuljtury v socyume [The life of language and culture in society]. Kemerovo-Jalta: KGhU: 268. (in Russian)

19. Selivanova O. O. (2012). Frazeologhija u dzerkali etnosvidomosti [Phraseology in the mirror of ethnic consciousness]. Cherkasy: 308. (in Ukrainian)

20. Soboleva P. A. (1984). Modelyrovanye slozhnykh prylaghateljnykh. [Modeling complex adjectives]. Problemy strukturnoj lynghvystyky. 1982. Moscow: Nauka: $67-81$.

21. Soboleva P. A. (1983). Transformacyonnye polja applykatyvnoj porozhdajushhej ghrammatyky v modelyrovanye slozhnykh slov [Transformational fields of applicative generative grammar and modeling of complex words]. Problemy strukturnoj lynghvystyky. Moscow: Nauka: 83-95.

22. Stepanov Ju. S. (2007). Koncepty. Tonkaja plenka cyvylyzacyy. [Concepts. Thin film of civilization]. Moscow: Jazyky slavjanskykh kuljtur: 448. (in Russian)

23. Telija V. N. (1977). Faktor kul'tury i vozrozhdenye frazeologhyzmov [The culture factor and the revival of phraseological units]. Moscow: 260. (in Russian)

24. Telija V. N. (1999). Pervoocherednye zadachy y metodologhycheskye problemy yssledovanyja frazeologhycheskogho sostava jazyka $\mathrm{v}$ kontekste kuljtury [Priority tasks and methodological problems of the study of the phraseological composition of the language in the context of culture]. Frazeologhyja v kontekste kuljtury. Moscow: Jazyky russkoj kuljtury: 203-211.

25. Terner M. (1998). Izbrannye trudy. Posobye dlja studentov [Selected Works. A handbook for students]. Prynghston: 298. (in Russian)

26. Tryr J. (1990). Izbrannyye trudy [Selected Works]. Moscow: 210. (in Russian)

27. Ufimceva N. V. (2012). Etnicheskij jazyk v uslovijakh kul'turnoj i jazykovoj polyfonii [Ethnic language in the context of cultural and linguistic polyphony]. Fylologhyja y kuljtura. Kazan': 124-135.

28. Fedina O. V. (2020). Frazeosemantychne pole konceptu ljudyna v rosijsjkij movi: funkcijno-praghmatychnyj aspect [Phraseosemantic field of the concept of man in the Russian language: functional-pragmatic aspect] (PhD Thesis), Dnipro: Oles Honchar Dnipro National University: 28.

29. Filin F. P. (1970). Ocherky po ystoryy jazykoznanyja do XIV stoletyja [Essays on the history of linguistics before the XIV century]. Voprosy jazykoznanija. Moscow: Nauka: 77-85.

30. Shepel Yu. A. (2010). K voprosu o nacyonal'no-kul'turnoj specyfike rechevoj dejatel'nosti v sovremennoj linghvistike [On the issue of the national and cultural specifics of speech activity in modern linguistics]. Naukovi zapysky Lughansjkogho nacionaljnogho universytetu. Vyp. IX Serija «Filologhichni nauky»: Zb. nauk. pracj 
[Pred'javlennja svitu v ghumanitarnykh dyskursakh XXI stolittja]. Lughansjkyj nac. un-t im. Tarasa Shevchenka. Lughansjk: DZ «LNU imeni Tarasa Shevchenka»: 112-117.

31. Shepel Yu. A. (2012). Slovoobrazovateljnyj rjad kak kompleksnaja edynyca slovoobrazovanyja [Derivative series as a complex unit of word formation]. N. M. Shanskyj - teoretik, praktik, pedaghogh: Materialy memorial'noj jubilejnoj mezhdunarodnoj nauchno-prakticheskoj konferencii. 22 nojabrja 2012. Symferopol: Dom Pysatelej im. Dombrovskogho: 80.

32. Shepel Yu. A. (2011). Formirovanie systemy kul'turnykh konceptov v ramkakh koghnitivnykh vozmozhnostej lichnosty [Formation of a system of cultural concepts within the framework of the cognitive capabilities of an individual]. Skhidnoslov'jans 'ka filologhija: zb. naukovykh prac'. Ghorlivs'kyj derzh. ped. in-t inozemnykh mov; Donecjkyj nac. un-t. Redkol.: S. O. Kochetova ta inshi, vol. 20. Movoznavstvo. Ghorlivka: Vydavnyctvo GhDPIIM: 19-43.

33. Shchur Gh. S. (1974). O tipakh leksycheskikh associacij v jazyke [About the types of lexical associations in the language]. Moscow: 154. (in Russian)

34. Jarceva L. Y. (1990). Chelovek telesnyj vo frazeologhyy [Bodily man in phraseology]. Kyev: 203. (in Russian)

35. Slovari i entsiklopedii na Akademike [Dictionaries and encyclopedias on Academician]. URL: dic.academic.ru 